\title{
RATIONING WITHOUT JUSTICE: \\ CHILDREN AND THE AMERICAN HEALTH SYSTEM
}

\section{SARA ROSENBAUM†}

\section{INTRODUCTION}

Of all the hardships and inequities in the United States caused by the absence of a reasoned approach to health care resource allocation, perhaps none is more stark or poignant than the nation's treatment of children. The United States stands virtually alone among western industrialized democracies in failing to assure at least minimum health care for all pregnant women and children. ${ }^{1}$ The voluntary employment-based health insurance system, the central health care financing mechanism for working age Americans and their families, leaves out forty percent of all children. ${ }^{2}$ Medicaid, the largest source of public health care financing for children, covers less than half of all children without employer benefits; ${ }^{3}$ moreover, the federal government and some states, responding to the growing economic burdens created by the program, frequently aim their budget cutting knives at expenditures on women and children, who are without the political defenses needed to fight back. The United States offers children no floor of health care decency as it does for the elderly through the Medicare program. There is no body of case law, no constitutional guarantee, that assures all children access to comprehensive, basic health care regardless of ability to pay. Instead, children who today are the poorest Americans are also among the most likely to be medically underserved.

The consequences of this cumulative, national neglect of children are found in neonatal intensive care wards, hospital emergency clinics, special education programs for disabled

† J.D., Senior Staff Research Scientist, The George Washington University, Center for Health Policy Research.

I See Bret C. Williams \& C. ARDEN Miller, National GTR. For Clinical INFANT Programs, PReventive Health CaRE For Young CHILdREN: Findings From A 10-CounTry STUdy AND DiREcTIONS FOR UNITEd STATES POLICY 3 (1991). Infant health and survival in the United States compare unfavorably with Belgium, Denmark, France, Germany, Ireland, the Netherlands, Norway, Spain, Switzerland, and the United Kingdom. See id.

2 See Sara Rosenbaum et al., Children's Defense Fund, Children and Health INSURANCE 16 (1992).

${ }^{3}$ See id. at 10. 
preschool and school age children, and on the faces of death certificates for thousands of American children who die each year from preventable causes. The ultimate paradox of this failed policy toward children is that it not only needlessly claims so many young lives but that it also helps perpetuate our costly health care system. This paradox makes adoption of a national child health policy central to any new approach to allocating health resources, whether by price, quantity, health outcome, or some combination of the three.

This Commentary reviews the health status of American children and presents information on children's insurance coverage and access to health services. It argues that much of the poor health among children today can be traced to their lack of access to even basic health services. Finally, it sets forth overall national health reform recommendations for children.

\section{The HEALTH OF AMERICA's CHILDREN}

Good health is one of the basic hopes that all parents have for their children. For far too many American children, however, the chances of being born healthy and growing up healthy approximate those of children who live in countries far less wealthy than our own. In the case of certain key child health indicators, many U.S. communities measure poorly compared to third world nations. In the nation that spends more per capita on health care than any other, black infants die at rates higher than those for babies born in Jamaica or Trinidad and Tobago; ${ }^{4}$ immunization rates for infants and toddlers in the nation's capital rival those of Haiti. ${ }^{5}$

Health care is crucial for all children, but it is by no means the only factor that influences child health status. It is nearly impossible to discuss the health of children today without considering their poverty. In 1989, 12.6 million American children-one in five-lived below the federal poverty level, a twenty percent increase over a tenyear period. ${ }^{6}$ Nearly one in four young children under age six and

${ }^{4}$ See Sara Rosenbaum et al., Children's Defense fund, The Health of AMERICA'S CHILDREN 18 (1991) [hereinafter THE HEALTH OF AMERICA'S CHILDREN].

${ }^{5}$ See ChILdRen's Defense Fund, BRight Futures OR BroKen Dreams: The Status OF THE ChILDREN OF THE District OF COLUMbia AND AN INVESTMENT AGENDA FOR THE 1990s 26 (1991).

${ }^{6}$ See Clifford M. Johnson et al., Children's Defense Fund, Child Poverty IN AMERIGA 5 (1991). 
two in five black and Latino children were poor; ${ }^{7}$ overall, children were almost twice as likely as adults to be poor. ${ }^{8}$

Poverty affects child health in two ways. First, poverty significantly elevates children's risk of death and disability by exposing them to environmental and social conditions that nonpoor children are far less likely to face. ${ }^{9}$ Second, poverty robs children of access to health care: poor children are significantly more likely to lack health insurance, and poor families frequently live in isolated inner city and rural communities, far from sources of either affordable or accepting care. ${ }^{10}$

When poor children finally do obtain health care, it is far too often provided in severely overcrowded emergency rooms. Moreover, it is all too often delayed for reasons of cost, distance, or fear of treatment by the health care system, until a health need has escalated into a crisis. A baby's fever becomes meningitis; a strep throat becomes rheumatic fever; a woman's pregnancy becomes a medical emergency. The reason for these disasters is not that parents do not care: incessantly overcrowded waiting rooms in the relative handful of good community health clinics that are available to poor and medically underserved families with children are a testament to the effort these families will make to get care for their children. These disasters happen mainly because of the absence of a basic health care system for children.

No family can afford a fundamental human necessity as expensive as health care on its own. Virtually all families need sizable economic subsidies in order to pay for care. Thousands of communities need economic assistance to attract, support, and retain an adequate supply of health care providers. But the nation has managed to develop a system that supplies adequate health care to only a portion of all American children and that leaves millions uninsured and underserved.

Regardless of whether interventions beyond or in addition to medical care affect the health of children, all children need medical care. Were childhood poverty to disappear tomorrow, some of the most blatant health status and health care access problems would

7 See id. at 7.

8 See id. at 5.

${ }^{9}$ See LoRRaine V. KleRman, National CTR. FOR CHILdREN IN POVERTY, ALIVE and Well?: A Research and POlicy Review of Health Programs for POOR YOUNG CHILDREN 19 (1991).

${ }^{10}$ See Robert J. Blendon et al., Access to Medical Care for Black and White Americans: A Matter of Continuing Concern, 261 JAMA 278, 280 (1989). 
abate, but they would by no means disappear. Employment-based health insurance, which for the last five decades has been the central mechanism for distributing health resources to working families with children, shows widespread signs of crumbling, particularly in the case of coverage of minor dependents. Without aggressive intervention, the health problems reviewed below (which are frequently associated only with the poor) will confront ever greater numbers of children. Thus, although childhood poverty is intimately related to poor child health, the threats to child health transcend simple measures of poverty.

\section{A. Measures of Child Health}

There are certain basic indicators that most health researchers consider key measures of child health. This Commentary reviews data on five of these basic indicators: infant birthweight; prenatal care; infant and child mortality; infant mortality by cause; and childhood immunization status. ${ }^{11}$ These are bellwether indicators that provide a sentinel picture of the health of children. Each is measurable, and each can be improved with known, relatively inexpensive, and highly cost-effective interventions.

\section{Infant Birthweight}

In 1988, over 270,000 infants-6.9\% of all U.S. infants born that year-were born at low birthweight (weighing less than 5.5 pounds at birth). ${ }^{12}$ Infants born at low birthweight account for two-thirds of all neonatal mortality (deaths within the first twenty-eight days of life) and are twenty times more likely than normal weight infants to die during the post-neonatal period (twenty-eight days to one year). ${ }^{13}$ Low birthweight infants are also at significantly greater risk for such lifelong disabilities as cerebral palsy, autism, and retardation. ${ }^{14}$ Poverty and access to health care are the major determinants of low birthweight. ${ }^{15}$

11 These measures, along with several others, are the ones identified by the United States Public Health Service in its initiative to assess and monitor the health of the American population. See PUBlic Health SERV., U.S. DEP'T OF HEALTH \& HUMAN SERVS., HEALTHY PEOPLe 2000, at 9-12, 70 (1991).

${ }^{12}$ See THE HEALTH OF AMERICA's CHILDREN, supta note 4, at 7.

13 See INSTITUTE OF MEDICINE, PREVENTING LOW BIRTHWEIGHT 29 (1985).

14 See id. at 31-32.

${ }^{15}$ For a detailed list of principal risk factors for low birthweight, see id. at 51 . 
America has one of the lowest rates of birthweight-specific infant mortality in the world. This phenomenon is attributable to the relatively widespread ${ }^{16}$ availability of advanced (and extraordinarily expensive) neonatal intensive care technology, which can keep extremely small infants alive and significantly reduce both death and severe disability. ${ }^{17}$

Among all nations, however, the United States has an extremely high incidence of low birthweight. It is this excessively high frequency of low birthweight births (the nation ranked twenty-eighth in the proportion of infants born at low birthweight in a survey of selected countries over the period $1980-1988)^{18}$ that underlies our elevated infant death rates. Although seven percent of all births are low birthweight, sixty percent of all infant deaths annually occur among low birthweight infants. ${ }^{19}$

As with other key measures of child health, data on low infant birthweight are collected by race and ethnicity, not by family income. Because of the lack of direct economic measures, health researchers commonly use race as a proxy in examining the health status of low income children. ${ }^{20}$ Black children as a group are exceedingly poor, and thus their health indicators are particularly instructive. ${ }^{21}$

${ }^{16}$ Significant disparities in access to specialized inpatient care for sick newborns on the basis of source of insurance coverage have been documented, however. See Paula A. Braveman et al., Differences in Hospital Resource Allocation Among Sick Newborns According to Insurance Coverage, 266 JAMA 3300, 3300-08 (1991).

${ }^{17}$ See THE HEALTH OF AMERICA's CHILDREN, supra note 4, at 8.

18 See id. at 9.

${ }^{19}$ See id. at 8.

${ }^{20}$ See, e.g., KLERMAN, supra note 9, at 4 (explaining that research typically uses documentable demographic factors, such as race, as proxies for economic status when evaluating health data).

${ }^{21}$ At some point there may be certain differences in birthweight by race that survive economic and health insurance controls. But experts believe that these underlying racial disparities are of far less significance than those related to income. See, e.g., Paul H. Wise et al., Racial and Socioeconomic Disparities in Childhood Mortality in Boston, 313 NEW ENG. J. MED. 360, 361-62 (1985) (noting that in a study of child deaths in Boston between 1972 and 1979, mortality for both white and black neonates was inversely related to median family income, though excess mortality was evident among blacks in all income groups). The impact of poverty on the health of black infants and children can be seen in the fact that black infants born to women with high educational attainment (a common proxy for income) have a significantly lower incidence of low birthweight than black infants born to mothers with low educational attainment. See Joel C. Kleinman \& Samuel S. Kessel, Racial Differences in Low Birth Weight: Trends and Risk Factors, 317 NEW ENG. J. MED. 749, 750 (1987). 
In 1988 , thirteen percent of all black children were born at low birthweight. The disparity between black and white low birthweight rates that year stood at 2.32:1-the widest gap since birthweight data by race were first collected in 1969. ${ }^{22}$ The elevated rate of low birthweight which affects one in every eight black infants born in the United States is a primary cause of the high U.S. black infant mortality rate. ${ }^{23}$

\section{Prenatal Care}

Prenatal care has a significant impact on the incidence of low birthweight and, consequently, on infant death and disability. ${ }^{24}$ Infants born to women who receive comprehensive prenatal care that begins early (by or before the third month of pregnancy), and that continues throughout pregnancy, are significantly likely to be born at full term and at normal birthweight. Pregnancy care permits health care providers to detect and treat the many conditions that can lead to infant (and maternal) death and disability. ${ }^{25}$ It is also highly cost-effective. Savings to the health care system resulting from reducing the incidence of low birthweight (and thus the high long- and short-term costs associated with treating low birthweight infants) have been estimated at more than three dollars for every dollar spent. ${ }^{26}$

In 1988, one in four U.S. infants was born to a woman who failed to begin care early in pregnancy. Among black infants, two in five were born to mothers who failed to receive early care. ${ }^{27}$ Babies born to women under age twenty ${ }^{28}$ are especially at risk for delayed prenatal care. In 1988, only fifty-three percent of all infants born to women ages nineteen and younger had mothers who began prenatal care early in pregnancy. ${ }^{29}$

22 See The HeALTH OF AMERICA's CHILDREN, supra note 4, at 8.

${ }^{23}$ See INSTITUTE OF MEDICINE, supra note 13, at 27.

24 See id. at 132.

25 See id. at 146 .

${ }^{26}$ See id. at 232.

27 See THE HEALTH OF AMERICA's CHILDREN, supra note 4, at 10.

28 The United States has the highest rate of adolescent pregnancy among industrialized nations. See Elise F. Jones et al., Teenage Pregnancy in Developed Countries: Determinants and Policy Implications, 17 FAM. PLAN. PERSP. 53, 54 (1985). Infants born to women under twenty face an elevated risk of death. Experts in adolescent pregnancy believe that the high rate of childbearing among young American women is heavily attributable to elevated poverty rates and lack of access to contraceptive services.

${ }^{29}$ See THE HEALTH OF AMERICA's ChildREN, supra note 4, at 4. 
Numerous studies have identified financial barriers as the single greatest impediment to the receipt of prenatal care in the United States. ${ }^{30}$ A 1989 report prepared for the President by an intercabinet task force (whose study and findings were withheld by the Bush Administration and subsequently leaked to the press) ${ }^{31}$ asserted that financial impediments to prenatal care prevented thousands of women from receiving known and effective maternity services. $^{32}$ Access to currently available types of maternal and infant health care, the report concluded, could save the lives of approximately 10,000 infants annually and could reduce the incidence of lifelong disability for another $100,000 .^{33}$ Savings as high as $\$ 380,000$ per infant could be achieved. ${ }^{34}$ The Task Force estimated the excess costs of failing to provide these services at approximately seven billion dollars annually in lost productivity. ${ }^{35}$

The link between financial barriers and prenatal care utilization is most evident when prenatal care use over time is examined. Following enactment of Medicaid and the creation of other key health programs for the poor and underserved in 1965, U.S. spending on health care for the poor increased significantly. ${ }^{36}$ Between 1969 and 1980, the proportion of women who received early care rose by nearly fifty percent among black mothers. ${ }^{37}$ During the 1980s, however, as spending on health services for the poor dropped, ${ }^{38}$ and as the number of Americans without access

${ }^{30}$ See, e.g., InstmUTte of MEdICINE, Prenatal CARE: REACHING Mothers, REACHING INFANTS 17-18 (Sarah S. Brown ed., 1988) (stating that socioeconomic status is the major determinant of both health status and the use of medical services; despite the cost-effectiveness of prenatal care no progress has been made since 1980 in increasing the delivery of prenatal care to poor women); INSTITUTE OF MEDICINE, supra note 13, at 153-57 (citing specific studies supporting this relationship including those of Norris and Williams, Schwartz and Poppen, and Chao et al., and pointing out that in the Chao study, when poor women who had obtained no prenatal care were asked why, over half mentioned financial difficulties); NATIONAL COMM'N TO PREVENT INFANT MORTALITY, DEATH BEFORE LIFE: THE TRAGEDY OF INFANT MORTALITY 14 (1988) (noting that the health of pregnant women and infants depends disproportionately on wealth).

${ }_{31}$ See Robert Pear, Study Says U.S. Needs to Attack Infant Mortality, N.Y. TIMES, Aug. 6,1990 , at A1, B9.

32 See WhITE House TASR Force, INFANT MORTALITY IN THE UNITED STATEs 2-4 (1989) [hereinafter WHITE HOUSE REPORT].

${ }^{33}$ See id. at 4.

${ }^{34}$ See id. at 21.

${ }^{35}$ See id.

36 See Karen Davis \& Cathy Schoen, Health and the War on Poverty: A TEN YEAR APPRAISAL 49, 56-62 (1978).

37 See THE HEALTH OF AMERICA'S CHILDREN, supra note 4, at 10 tbl. 9.

${ }^{38}$ In 1988 Congress mandated Medicaid coverage for all poor pregnant women, 
to private insurance increased, the proportion of infants born to women receiving early prenatal care actually declined slightly. ${ }^{39}$

\section{Infant and Child Mortality}

Infant mortality rates mirror the high rate of low infant birthweight and depressed access to maternal and child health services. In 1988, the overall infant mortality rate stood at 10.0 deaths per 1000 live births. ${ }^{40}$ Of the nearly 40,000 infant deaths that year, one quarter are considered preventable. ${ }^{41}$

Infant deaths are not equally distributed. The black/white infant mortality "gap" in 1987 stood at 2.08:1, the widest disparity since 1940 , when infant deaths were first reported nationally by race. ${ }^{42}$ Had the black infant mortality rate been as low as the rate for white infants, over 400,000 fewer black infants would have died between 1940 and $1988 .{ }^{43}$ Black infants are more likely to die than children born in many far poorer nations. ${ }^{44}$ Overall, black U.S. infants were more likely to die in 1989 than babies born in Cuba, Czechoslovakia, Poland, or Jamaica. ${ }^{45}$

\section{Infant Deaths by Cause}

When infant deaths are examined by cause, the disparity between poor and nonpoor infants becomes even starker. Black and white infant death rates from congenital anomalies (nonpreventable birth defects) were virtually identical in 1988, but black infants were 3.88 times more likely to die from disorders relating to short gestation and low birthweight, 2.64 times more likely to die

a major advance in federal health policy. See Medicare Catastrophic Coverage Act of 1988, Pub. L. No. 100-360, $\$ 302,102$ Stat. 683, 750-54 (codified as amended at 42 U.S.C. $\$ 1396 \mathrm{a}(\mathrm{a})(10)(\mathrm{A})(\mathrm{i})$, ( $l$ ) (Supp. I 1989)). The import of these changes, however, is just now beginning to be measured in terms of the number of births affected. The reforms came too late in the decade to affect prenatal care patterns during the Reagan Administration.

39 See THE HEALth OF AMERICA's CHILdREN, supra note 4, at 10.

40 See id. at 4.

${ }^{41}$ See WHITE HOUSE REPORT, supra note 32, at 1.

42 See THE HEALTH OF AMERICA's CHILDREN, supra note 4, at 14.

${ }^{43}$ See id.

44 In 1986, the black infant death rate in America's largest cities ranged from 13.8 deaths per 1000 live births in Columbus, Ohio, to 24.6 deaths per 1000 in Indianapolis. These rates were considerably higher than those of other first world countries. See DANA Hughes eT AL., ChILDREN's DEFENSE FUND, THE HEALTH OF AMERICA'S CHILDREN: MATERNAL AND CHILD HEALTH DATA BOOK 14, 156 (1989).

${ }^{45}$ See THE HEALTH OF AMERICA's CHILDREN, supra note 4 , at 18. 
from maternal complications of pregnancy, 2.21 times more likely to die from perinatal infections, 2.39 times more likely to die from septicemia, 2.09 times more likely to die from meningitis, and 3.2 times more likely to die from homicide. ${ }^{46}$

Equally disturbing are death rates among young children. The mortality rate for U.S. children under age five in 1989 placed the nation nineteenth worldwide. ${ }^{47}$ Nations such as Ireland and Italy, far poorer than our own, had lower child death rates. A baby born in Japan is twice as likely to reach its fifth birthday as one born in this country. ${ }^{48}$

\section{Childhood Immunization Status}

Of all the adverse health trends affecting U.S. children, none has been more disturbing than falling childhood immunization rates and the consequent outbreaks of preventable disease. The most glaring recent result of the childhood immunization crisis has been a threeyear long outbreak of measles, affecting over 55,000 children and causing eighty-nine deaths in 1990 alone. ${ }^{49}$ Because measles is the most contagious of all childhood diseases, the widespread epidemic that is now only beginning to abate (chiefly because so many children have been affected) is a harbinger of other disease outbreaks to come, since the epidemic is symptomatic of low immunization rates generally.

Childhood immunization status is an indicator for wider health trends. For example, it is a measure of health status, because it offers such powerful and total protection against disease, disability and death. It is also a measure of access to primary health care generally, because immunizations represent perhaps the most basic of all primary pediatric health services. Thus, falling childhood immunization rates underscore how little this nation invests in even the most basic known and proven health interventions for children.

Declining immunization status among infants and toddlers (which has most strongly affected children living in the poorest communities) is the result of several related systemic failures. First, vaccine prices have wildly escalated over the past decade because of threats of malpractice, price inflation generally, and price hikes by

${ }^{46}$ See id. at 16.

47 See id. at 18.

48 See id.

49 See Joseph TIang-Yau LiU \& SARa Rosenbaum, GhLdRen's Defense Fund, MEDICAID AND CHILDHOOD IMMUNIZATIONS: A NATIONAL STUDY 7 (1992). 
sole manufacturers. Vaccines against diphtheria, pertussis, and tetanus rose in cost by $2921 \%$ between 1981 and 1991; oral polio vaccine costs rose by $350 \%$ per dose; and vaccines against measles, mumps, and rubella rose in cost by $171 \%$ per dose. ${ }^{50}$

The second systemic cause of immunization status decline has been the exodus of private physicians out of the "vaccination business." As vaccine prices have spiraled upward, many physicians, reacting both to the high cost and the lack of health insurance among so many of their child patients, ceased providing immunizations and began referring patients to public health clinics. A recent study of physician vaccination service patterns in one major metropolitan area found that $84.4 \%$ of responding pediatricians and $66.5 \%$ of responding family physicians reported referring at least some of their young patients to public clinics. ${ }^{51}$

A third factor has been the utter erosion of the nation's system of local public health clinics and federally funded community health centers. These clinics are presently operating far below their 1981 real-dollar funding levels, and thus have neither the staff, supplies, nor resources to accommodate their current patients, much less the deluge of patients referred from private practices. Historically these clinics have delivered perhaps one-half to one-third of all childhood vaccinations administered in the United States. They are totally unprepared financially to become the prime source of childhood vaccinations. For example, during the height of the measles epidemic, seventy percent of federally funded community health centers responding to one survey reported experiencing shortages of measles vaccine from the federal Centers for Disease Control and were without the funds to purchase adequate supplemental doses to make up for the shortfall. ${ }^{52}$

The inevitable outcome of these combined trends was a massive outbreak of measles in major urban areas across the country. In 1990 alone there were more than 27,000 reported cases of measles nationwide. ${ }^{53}$ Although the numbers have declined since then (a trend chiefly attributable to the fact that the disease simply has run

${ }^{50}$ See id. at 8.

51 See Joanne M. Schulte et al., Changing Immunization Referral Patterns Among Pediatricians and Family Practice Physicians, Dallas County, Texas, 1988, 87 PEDIATRICS 204-05 (1991).

52 See Sara Rosenbaum, Children's Defense Fund, The Health of America's CHILDREN: VACCINE SUPPLY AND LOW INCOME CHILDREN: BARRIERS FACED BY Community and Migrant Health Center Patients 20 (1991).

${ }^{53}$ See LiU \& Rosenbaum, supra note 49 , at 7. 
its course among the non-immunized population), experts warn that this lull will once again erupt into disease outbreaks if major reforms in the availability of inexpensive vaccination services are not instituted. ${ }^{54}$

\section{B. Overview}

The portrait of children which emerges from this brief overview is extraordinarily disturbing. Interventions that save enormous sums (more than three dollars saved for every dollar spent on prenatal care; ${ }^{55}$ between ten and fourteen dollars saved for every dollar spent on childhood vaccines ${ }^{56}$ ) are eschewed on the grounds that their provision costs more than the government can afford; ${ }^{57}$ yet the failure to pursue these interventions is costing the U.S. health system literally billions of dollars in medical and long-term educational and social expenditures. ${ }^{58}$ These costs are even greater when the long term cost to the U.S. economy in needlessly lost healthy children and productive lives is taken into account.

\section{ChILdREN's Access to HeAlth CARE}

Access to health care is closely associated with health insurance coverage and the availability of health services, both of which pose major problems for children.

54 Interview with Dr. Edgar Marcuse, Chairman, Subcommittee on Financing, National Vaccine Advisory Committee, in Seattle, Wash. (Nov. 1, 1991).

${ }^{55}$ See INSTITUTE OF MEDICINE, supra note 13, at 232.

56 See OFFICE OF TECHNOLOGY ASSESSMENT, U.S. CONGRESS, HEALTHY CHILDREN: INVESTING IN THE FUTURE 133-35, 254-55 (1988).

${ }^{57}$ Indeed, it was the White House Task Force's request in its 1989 report for an additional $\$ 500$ million of annual spending that reportedly contributed to the study's suppression. See Pear, supra note 31, at A1.

${ }_{58}$ The long-term cost of low birthweight to the U.S. health and social service system has been estimated at billions of dollars. See INSTITUTE OF MEDICINE, supra note 13, at 229; see also Gail Ross et al., Educational Status and School-Related Abilities of Very Low Birth Weight Premature Children, 88 PEDIATRICS 1125 (1991) (finding that an estimated $48 \%$ of low birthweight, premature infants, as opposed to $15 \%$ of fullterm infants, will require special education). 


\section{A. Health Insurance}

The primary mechanism for insuring working-age Americans and their children is employer-based health insurance, a voluntary health insurance system that has occupied center stage in the United States for the past half century. The flaws of the employer insurance system were readily visible from the start, since it excluded by definition tens of millions of nonworkers and retirees (an exclusion that eventually necessitated the creation of Medicare and Medicaid). ${ }^{59}$ It was assumed, however, that the employer system would adequately address the needs of workers and their families, even though by the mid-1970s it was apparent to many that this was not the case. ${ }^{60}$

Over the past decade, any semblance of the employment-based insurance system's adequacy has disappeared. Massive labor shifts away from high-paying jobs with good fringe benefits to low-paying jobs with few benefits have left millions of workers vulnerable to loss of coverage. The recessions of the early 1980s and the early 1990 s once again underscored the system's vulnerability to unemployment. Finally, explosive costs have led to widespread efforts by employers to cut the expense of insurance for those workers still covered by the employment-based system.

Employers have begun to scale back their subsidization of employment health benefits (particularly for family coverage) at a time when eroding family income has made it increasingly difficult for workers to assume responsibility for these large, uncovered costs. Between 1980 and 1989, the proportion of medium- and large-sized firms fully subsidizing the cost of employer benefits for both workers and their family members dropped from sixty-four to forty-six percent. ${ }^{61}$ At the same time, deductibles and coinsurance costs were also allowed to rise, adding further to workers' loss of subsidized coverage.

The impact of these trends on children has been enormous. As indirect beneficiaries of the employer system, children are particu-

${ }^{59}$ For a description of the events leading up to the enactment of Medicare and Medicaid, see PaUl STARR, THE SOCIAL TRANSFORMation OF AMERICAN MEDICINE 225-78 (1982).

${ }^{60}$ In 1976 Jimmy Carter campaigned on national health insurance and attempted during the first two years of his presidency to gain enactment of national health legislation. Although the inequities and burdens of the employer-based system were quite clear, no consensus on an NHI plan could be reached. See id. at 411-14.

${ }^{61}$ See Rosenbaum ET AL., supra note 2, at 25. 
larly vulnerable to loss of coverage as a result of unemployment, labor shifts, and insurance cost increases. Moreover, changes in family living arrangements also can affect children's coverage. The death of a working parent or divorce easily can cost a child his or her connection to work-based insurance.

By 1990, as Table I shows, only slightly more than sixty percent of all children under eighteen had employer coverage. Among black and Latino children, fewer than forty percent had "mainstream" employer coverage. More than eight million children were completely uninsured; but had it not been for Medicaid (the largest source of public third party financing for children) the number of completely uninsured children would have surpassed eighteen million. ${ }^{62}$ Without Medicaid, the number of completely uninsured black children probably would have been higher than the number with employer benefits.

Two national household surveys of insurance coverage conducted by the federal government illustrate that it is children in low and moderate income households (with family income between $\$ 11,000$ and $\$ 45,000$ for a family of four in 1991) and those in working families who have been most vulnerable to the loss of coverage. ${ }^{63}$ These families have historically relied on employer coverage to insure their children; they are too "well off" for their children to qualify for Medicaid (which covers only children living in families below the federal poverty level). Yet these families cannot possibly afford to buy private coverage, which can now easily surpass $\$ 5000$ annually for family health insurance.

${ }^{62}$ See $i d$. at 10 . Of the 11.9 million Medicaid-covered children under $18,9.7$ million would have been completely uninsured without the program. Approximately $20 \%$ of Medicaid insured children have some private insurance, although this insurance is assumed to be of a very limited nature, with far fewer benefits than Medicaid provides. See id.

${ }^{63}$ See id. at 13-20 (analyzing data from the two government surveys, NMCES and NMES, to determine the impact of the loss of coverage on children). The National Medical Care and Expenditure Survey of 1977 (NMCES) and the National Medical Expenditure Survey of 1987 (NMES) were special year-long surveys of medical care use, expenditures, and health insurance coverage of the U.S. population. They were conducted by the U.S. Department of Health and Human Services and provide an unparalleled wealth of information on changing insurance coverage patterns. For more on the details of these two surveys, see id. at 34-35. 


\section{TABLE $I^{64}$}

HEALTH INSURANCE GOVERAGE STATUS OF ALL

CHILDREN YOUNGER THAN 18, BY RACE/ETHNICITY, 1990

\begin{tabular}{|c|c|c|c|c|c|c||}
\hline & Total & $\begin{array}{c}\text { Covered } \\
\text { by } \\
\text { Public } \\
\text { or } \\
\text { Private } \\
\text { Insurance }\end{array}$ & $\begin{array}{c}\text { Covered } \\
\text { by Any } \\
\text { Private } \\
\text { Insurance }\end{array}$ & $\begin{array}{c}\text { Covered } \\
\text { by } \\
\text { Employer- } \\
\text { Based } \\
\text { Insurance }\end{array}$ & $\begin{array}{c}\text { Covered } \\
\text { by } \\
\text { Medicaid }\end{array}$ & $\begin{array}{c}\text { Uninsured } \\
\text { Through- } \\
\text { out the } \\
\text { Year }\end{array}$ \\
\hline $\begin{array}{c}\text { All Races } \\
\text { Number } \\
\text { Percent }\end{array}$ & 65,049 & 56,634 & $\begin{array}{l}46,369 \\
71.3 \%\end{array}$ & $\begin{array}{l}39,964 \\
61.4 \%\end{array}$ & $\begin{array}{l}11,993 \\
18.4 \%\end{array}$ & $\begin{array}{l}8,414 \\
12.9 \%\end{array}$ \\
\hline $\begin{array}{c}\text { White } \\
\text { Number } \\
\text { Percent }\end{array}$ & 51,929 & 45,444 & 39,484 & 34,356 & 7,132 & 6,486 \\
\hline $\begin{array}{c}\text { Black } \\
\text { Number } \\
\text { Percent }\end{array}$ & 10,162 & 8,695 & 4,954 & 4,048 & 4,201 & 1,467 \\
\hline $\begin{array}{l}\text { Latino } \\
\text { Number } \\
\text { Percent }\end{array}$ & 7,457 & 5,344 & 3,356 & 2,893 & 2,237 & $12.5 \%$ \\
\hline
\end{tabular}

Tables II and III show that between 1977 and 1987 employer coverage of low income children dropped by more than fifteen percentage points, while private coverage of children in every type of employed household also declined. This decline was particularly noticeable in the case of children living in two-parent households with only one wage-earner, the "traditional" working American family.

${ }^{64}$ Table $\mathrm{I}$ is adapted from id. at $7 \mathrm{tbl}$. 1A. Persons of Latino origin may be of any race. See $i d$. 
TABLE II ${ }^{65}$

EMPLOYMENT-RELATED INSURANCE,

BY RAGE/ETHNICITY

AND INCOME,

$1977 \& 1987$

\begin{tabular}{|c|c|c|}
\hline & \multicolumn{2}{|c|}{ Year } \\
\hline & 1977 & 1987 \\
\hline $\begin{array}{l}\text { All Children } \\
\text { Total } \\
\text { White } \\
\text { Black } \\
\text { Latino }\end{array}$ & $\begin{array}{l}72.8 \% \\
78.2 \% \\
52.5 \% \\
50.7 \%\end{array}$ & $\begin{array}{l}62.9 \% \\
71.3 \% \\
38.1 \% \\
39.4 \%\end{array}$ \\
\hline $\begin{array}{l}\text { Poor Children } \\
\text { Total } \\
\text { White } \\
\text { Black } \\
\text { Latino }\end{array}$ & $\begin{array}{l}27.5 \% \\
40.0 \% \\
11.0 \% \\
12.5 \%{ }^{67}\end{array}$ & $\begin{array}{l}23.0 \% \\
31.5 \% \\
15.9 \% \\
16.1 \%\end{array}$ \\
\hline $\begin{array}{l}\text { Low Income Children } \\
\text { Total } \\
\text { White } \\
\text { Black } \\
\text { Latino }\end{array}$ & $\begin{array}{l}63.4 \% \\
69.0 \% \\
50.5 \% \\
49.6 \%\end{array}$ & $\begin{array}{l}47.0 \% \\
52.1 \% \\
34.2 \% \\
38.3 \%\end{array}$ \\
\hline $\begin{array}{l}\text { Middle Income Children } \\
\text { Total } \\
\text { White } \\
\text { Black } \\
\text { Latino }\end{array}$ & $\begin{array}{l}83.6 \% \\
84.2 \% \\
83.7 \% \\
71.7 \%\end{array}$ & $\begin{array}{l}79.0 \% \\
81.3 \% \\
69.5 \% \\
64.5 \%\end{array}$ \\
\hline $\begin{array}{l}\text { Upper Income Children } \\
\text { Total } \\
\text { White } \\
\text { Black } \\
\text { Latino }\end{array}$ & $\begin{array}{l}85.4 \% \\
86.9 \% \\
76.8 \% \\
69.0 \%\end{array}$ & $\begin{array}{l}86.9 \% \\
87.3 \% \\
83.4 \% \\
77.5 \%\end{array}$ \\
\hline
\end{tabular}

65 Table II is adapted from RosenBaUM ET AL., supra note 2, at 15 tbl. 3. Persons of Latino origin may be of any race. See id.

${ }^{66}$ Defined as having incomes below the federal poverty level. See id.

${ }^{67}$ Standard error is greater than $30 \%$ of the estimate. See id.

${ }^{68}$ Defined as having incomes between $100 \%$ and $199 \%$ of the federal poverty level. See id.

${ }^{69}$ Defined as having incomes between $200 \%$ and $399 \%$ of the federal poverty level. See id.

${ }^{70}$ Defined as having incomes at $400 \%$ or greater of the federal poverty level. See id. 
TABLE III ${ }^{71}$

ChildRen With Private Insurance Coverage

BY PARENTS' EMPLOYMENT AND

RACE/ETHNICITY, 1977 \& 1987

\begin{tabular}{|c|c|c|}
\hline & \multicolumn{2}{|c|}{ Year } \\
\hline & 1977 & 1987 \\
\hline $\begin{array}{l}\text { Two Parents, Both Employed } \\
\text { Total } \\
\text { White } \\
\text { Black } \\
\text { Latino }\end{array}$ & $\begin{array}{l}89.6 \% \\
90.6 \% \\
84.1 \% \\
85.0 \%\end{array}$ & $\begin{array}{l}87.2 \% \\
88.8 \% \\
85.2 \% \\
72.4 \%\end{array}$ \\
\hline $\begin{array}{l}\text { Two Parents, One Employed } \\
\text { Total } \\
\text { White } \\
\text { Black } \\
\text { Latino }\end{array}$ & $\begin{array}{l}83.0 \% \\
85.4 \% \\
72.4 \% \\
63.9 \%\end{array}$ & $\begin{array}{l}73.3 \% \\
77.9 \% \\
62.1 \% \\
43.7 \%\end{array}$ \\
\hline $\begin{array}{l}\text { All Single Parents, Employed } \\
\text { Total } \\
\text { White } \\
\text { Black } \\
\text { Latino }\end{array}$ & $\begin{array}{l}66.0 \% \\
70.8 \% \\
62.1 \% \\
37.4 \%\end{array}$ & $\begin{array}{l}64.7 \% \\
75.2 \% \\
51.0 \% \\
35.9 \%\end{array}$ \\
\hline $\begin{array}{l}\text { Single Female Parents, Employed } \\
\text { Total } \\
\text { White } \\
\text { Black } \\
\text { Latino }\end{array}$ & $\begin{array}{l}64.9 \% \\
69.5 \% \\
62.3 \% \\
35.7 \%\end{array}$ & $\begin{array}{l}62.9 \% \\
74.1 \% \\
50.7 \% \\
33.5 \%\end{array}$ \\
\hline
\end{tabular}

Taken together these tables present a picture of an eroding private system of health insurance coverage for children, with only limited relief for the poorest children provided through Medicaid. As important as Medicaid has been for pregnant women and children, ${ }^{73}$ it is an inadequate substitute for private insurance

71 See Rosenbaum ET AL., supra note 2, at 17, tbl. 4. Persons of Latino origin may be of any race. See id.

${ }^{72}$ Children in single-parent, female-headed families comprise a subgroup of all children in single-parent families. See id.

${ }^{73}$ Medicaid is closely associated with dramatic improvements in children's use of health services. Between 1965, when Medicaid was enacted, and 1977, use of prenatal care and child health services among low income women and children rose significantly. See DAVIS \& SCHOEN, supra note 36 , at $49-91$. By 1980 , poor Medicaid 
because of low provider acceptance resulting from its depressed provider reimbursement levels and the stigma attached to the program and its enrollees. ${ }^{74}$ There is no public insurance safety net for children like the Medicare program for the elderly. Children without private coverage either obtain limited relief through Medicaid or go without.

In recent years Congress has enacted a lengthy series of Medicaid reforms designed to extend coverage to all poor children under age nineteen, ${ }^{75}$ and expand benefits to include coverage for all medically necessary health services for which federal Medicaid funding is available. ${ }^{76}$ Enacted during a period of general retrenchment in U.S. social spending on the poor, these reforms stand out as a "bright spot" in American health policy. Yet at the same time, many states, increasingly frustrated by the high cost of the Medicaid program, ${ }^{77}$ have proposed deep reductions in coverage and benefits. In addition, the Bush Administration has proposed to place an arbitrary ceiling on the amount of funds available to states to help them maintain the acute care portion of their Medicaid programs. ${ }^{78}$ In the case of both the proposed state and federal Medicaid cutbacks, the burdens of the reductions would fall most heavily on children.

Some states have proposed to reduce Medicaid coverage of children by reducing the number of families receiving Aid to Families with Dependent Children (AFDC). Although Medicaid coverage for young children is no longer limited to those whose family incomes meet welfare standards, ${ }^{79}$ eligibility for children

insured children were more likely to receive comprehensive preventive health care than poor children with private coverage, because of Medicaid's comprehensive coverage of preventive child health benefits. See Margo L. Rosenbach, The Impact of Medicaid on Physician Use by Low Income Children, 79 AM. J. PUB. HEALTH 1220, 1224 (1989).

${ }^{74}$ Even with national health insurance, physicians and other health providers would probably continue to avoid patients who, despite their insurance coverage, are perceived as undesirable. For example, studies comparing health utilization by race show that even when controlling for health coverage, significant racial disparities remain. See, e.g., Blendon et al., supra note 10, at 278-81.

${ }^{75}$ See 42 U.S.C.A. § 1396a(a)(10)(A)(i), (l)(1)(D) (West 1992).

76 See 42 U.S.C. \$ 1396d(a)(4)(B), (r) (Supp. I 1989).

${ }^{77}$ For Fiscal 1993, the U.S. Department of Health and Human Services projects that total federal Medicaid spending will exceed $\$ 84$ billion. See U.S. DEP'T OF Health \& HuMan SeRvs., THE FisCal YeAR 1993 Budget 50 (1992).

${ }^{78}$ See The President's Comprehensive Health Reform Program 61, 63-64 (Presidential White Paper, released Feb. 6, 1992) [hereinafter PRESIDENT's REFORM PROGRAM].

${ }^{79}$ Children born after September 30, 1983, are entitled to Medicaid so long as 
ages nine and older ${ }^{80}$ is still governed by welfare eligibility criteria. AFDC cutbacks would thus have a direct impact not only on children's subsistence income, but on their access to health insurance coverage as well. In cutting Medicaid by reducing AFDC grants, states limit the extent of their eligibility reductions almost entirely to children, since young families with children comprise nearly the entire AFDC population.

In the most publicized state Medicaid restructuring plan put forth in recent years, Oregon is seeking under special federal demonstration authority to extend Medicaid to indigent persons not now covered, while removing thousands of children from the program outright and eliminating coverage for medically necessary care for tens of thousands more. ${ }^{81}$ The Oregon plan would completely exempt elderly and disabled beneficiaries during at least the first biennium of the experiment and would reduce only a narrow range of services used by elderly beneficiaries during the second biennium (all long term care services would be permanently exempted). The Oregon plan is particularly noteworthy because its proponents have portrayed it as an example of reasoned health care rationing. Yet the plan would exempt over seventy-five percent of the state's Medicaid expenditures from cuts, and thus would leave the most expensive populations and services untouched.

At the same time that states are reducing health benefits to children, the President has similarly proposed deep cuts in Medicaid spending for poor children in order to provide some financial assistance to low income families unable to afford the cost of health insurance. The President's national health plan, unveiled in early February, extends tax credits to help poor uninsured Americans buy health insurance. ${ }^{82}$ Yet while he deliberately chose to remain silent on how his plan would be funded, the President included in his proposal one notable exception: the establishment of strict spending limits, unrelated to the cost of medical care, on that portion of the Medicaid program representing expenditures on

their family incomes fall below $133 \%$ of the federal poverty level in the case of children under age 6 , and below $100 \%$ of the poverty level in the case of children between the ages of 6 and 19. See 42 U.S.C.A. $\$ 1396 a(l)$ (West 1992).

${ }^{80}$ Because Medicaid coverage for all poor children under age 19 is phased in, beginning with children born on October 1, 1983, it will be 2002 before all poor children under 19 are entitled to coverage. See id. $\S 1396 \mathrm{a}(l)(1)(\mathrm{D})$.

${ }^{81}$ See Sara Rosenbaum, Mothers and Children Last: The Oregon Medicaid Experiment, 18 AM. J. L. \& MED. 97 (forthcoming 1992).

82 See PRESIDENT'S REFORM PROGRAM, supra note 78, at 2. 
women and children. Long-term care services (used overwhelmingly by the elderly) would not be subject to artificial growth limits. Once again, under the guise of shaping a more reasoned approach to health care spending in order to promote coverage for poor uninsured Americans, the Bush Administration specifically calls on one population in particular-the nation's poorest children-to bear the costs associated with improving health care coverage for the poor.

\section{B. Health Services}

As vital as health insurance is, it cannot solve all of the problems facing medically underserved children. More than forty million Americans, fifty-five percent of whom are women of childbearing age and children, live in areas of the country that have been designated by the federal government as "medically underserved" because of high poverty, poor health status and a shortage of primary health care providers. ${ }^{83}$ For these families, health insurance alone is an incomplete remedy. Their geographic isolation and poverty make them unattractive to the private health care system. Even were national health insurance enacted, it would provide only partial relief. The unattractiveness of these neighborhoods as private practice locations, coupled with the "trans-medical" health care needs of many poor families will inevitably discourage a widespread response from the private sector.

There are very few programs designed to provide comprehensive medical care in medically underserved communities. The most important are the community and migrant health center programs and the National Health Service Corps. Community and migrant health centers $^{84}$ are federally funded, comprehensive primary health clinics located in underserved communities. The National Health Service Corps, ${ }^{85}$ through its grants and scholarship programs, provides physicians, nurses, and other health professionals for these clinics, which frequently are unable to attract sufficient personnel themselves.

The record of migrant health centers and the Corps has been notable. Health centers (about two thirds of whose patients are

83 DANiEl Hawkins ET AL., LIVES in THE BaLANCE: A NATIONAL, STATE AND COUNTY PROFILE OF AMERICA'S MEDICALLY UNDERSERVED 10, 12 (1992).

84 See 42 U.S.C. $\$ \S 254 b-254 c$ (1988).

${ }^{85}$ See id. \$ 254d. 
women of childbearing age and children) have had a major impact on child health measures in the communities they serve, with major reductions in infant mortality and child morbidity measured. ${ }^{86}$ With their community governance systems, health centers have shown important staying power, bringing not only health care, but jobs and a sense of community involvement and control to the populations they serve.

Despite their achievements and importance, health centers have never been adequately funded. Today, there are sufficient health centers to serve approximately six million patients-less than twenty percent of all medicaily underserved persons. ${ }^{87}$ The personnel available through the Corps are similarly far fewer than the number needed. Recent years have seen some increases in funding for the programs and a renewed and growing attention to the importance of health resource development for the underserved as part of an overall national health strategy. Nonetheless, another 2500 health centers and at least 10,000 health professionals are estimated to be needed to reach all of the medically underserved communities designated to date. ${ }^{88}$

\section{CONCLUSION}

If rationing is defined as the reasoned allocation of available health resources, then the plight of American children is its antithesis. True rationing involves decreasing resource allocations in areas where spending is excessive and increasing allocations to underfinanced services and populations. Yet America's peculiar system of health care, which does promote miraculous health service breakthroughs, also makes curbing expenditures on the "overserved" virtually impossible. As a result, not only is there insufficient funding to increase spending on the underserved, but it is the most politically defenseless citizens who have borne the brunt of cutbacks as pressures to curb health care spending mount. Regard-

${ }^{86}$ See DAVIS \& SCHOEN, supra note 36 , at 178, 184-85.

87 See HAWKINS ET AL., supra note 83, at 42.

${ }^{88}$ These designations are a major understatement of need. Of nearly forty-three million medically uninsured, the vast majority (ninety-five percent) live in areas that ostensibly have sufficient numbers of physicians but whose sources of care appear to be inaccessible, as measured by the diminished health status of residents. See id. at 10. These Americans, termed medically underserved populations by the Public Health Service, are excluded from health care because of their uninsured or publiclyinsured status, their membership in racial and ethnic minority populations, and their poverty. 
less of whether the reduction in question is declining employer contributions to the cost of family coverage or state or federal Medicaid cutbacks, it is children who are left behind. The hallmark of American children today is their poverty, their medically uninsured and underserved status, and their political weakness, that has left them essentially defenseless in a world of health care cutbacks and that now threatens even the modest improvements made on their behalf.

There is no better example of health resource misallocation than the lack of a basic health system for all American children. Millions of children are uninsured, underinsured and underserved. By the end of the decade, if something is not done, half of all American children and eighty percent of all black children will lack private health insurance. ${ }^{89}$ The consequences of their growing exclusion from the health system are the deteriorating and stagnating measures of infant and child health discussed above, as well as unnecessarily high expenditures for children whose costly medical care is the price the nation pays for its neglect.

For approximately ten billion in 1992 dollars, all pregnant women and children could be given comprehensive health insurance coverage, neighborhood health centers could be developed in all medically underserved ares, and a basic public health infrastructure for children and families could be revived. ${ }^{90}$ This investment represents an approximate $1.5 \%$ increase in the national health budget. It neither includes offsetting savings resulting from children's improved access to early, comprehensive health services, nor does it include offsets for long-term savings resulting from improved health, lower prevalence of chronic disability, greater productivity and, smaller social and special education outlays.

An investment in child health is one that no nation can afford not to make and that virtually all civilized nations except the United States have chosen to pursue. Somehow these nations have been able to assure that, despite their political invisibility, children are cared for. American policy makers claim that the nation cannot

${ }^{89}$ See ROSENBAUM ET AL., supra note 2, at 16.

${ }^{90}$ This estimate is based on the author's calculation of the amount it would cost using data from the final report of the U.S. Bipartisan Commission on Comprehensive Health Care, see U.S. BIPARTISAN COMM'N ON COMPREHENSIVE HEALTH CARE (The PEPPER COMmission), A CALl FOR ACTION: FINAL Report 66 tbl. 2-4 (1990), combined with the estimated cost of developing primary care health clinics in all federally designated medically underserved areas in the United States. See HawkINS ET AL., supra note 83, at 10, 12. 
afford these protections; yet our strongest economic competitors, including Germany and Japan (nations whose infant mortality rates were double our own at the end of World War II) have found the modest resources they need to invest in their national futures.

An investment in American children ideally would come as part of an overall series of changes to make health care more accessible, affordable, and equitable for all Americans. But a national child health plan need not wait until policy makers have reached agreement on the myriad aspects of U.S. health care reform. It is inexpensive, effective, and doable. And it represents a first, significant step toward a reasoned approach to health care spending in America. 